\title{
WORKING WOMEN PREFERENCE AND SATISFACTION OF USING THE READY-TO-EAT FOOD PRODUCTS IN CHENNAI CITY
}

\author{
A.Ezhilarasi ${ }^{1} \square$ \\ ${ }^{1}$ Assistant Professor, Department of Commerce (CS), Sir Theagaraya College, Chennai, India
}
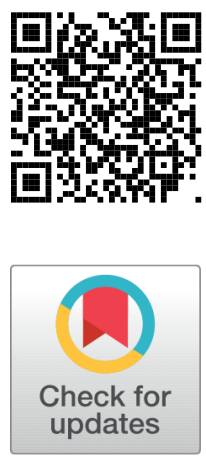

Received 2 April 2021

Accepted 18 April 2021

Published 30 April 2021

Corresponding Author

A.Ezhilarasi,ezhilvkk@gmail.com

DOI 10.29121/

granthaalayah.v9.i4.2021.3872

Funding: This research received no specific grant from any funding agency in the public, commercial, or not-for-profit sectors.

Copyright: (C) 2021 The Author(s). This is an open access article distributed under the terms of the Creative Commons Attribution License, which permits unrestricted use, distribution, and reproduction in any medium, provided the original author and source are credited.

\section{ABSTRACT}

Aim: The present study aims to assess the working women's Preference and satisfaction of using the Ready-to-Eat products in Chennai city.

Data Sources: The study utilized primary and secondary sources of data. The secondary sources of data were obtained from the research articles, newspapers, and weekly magazines. The primary data sources were collected from the working women who are using the Ready-to-Eat food products in the study region-the primary data obtained from working women's workplaces and their residence place.

Sampling Technique \& Size: The study employed the convenience sampling method. Overall, 300 structured questionnaires were distributed, out of which 291 filled questionnaires were collected from the working women.

Findings: The study found that the working women positively preferred for consumption of Ready-to-Eat food products. The working women's felt that the ready-to-eat food products readily available for the preparation of food products. The working women also viewed that the availability of ready-to-eat food products quickly. The study also found that the working women are delighted with the consumption of Ready to Food products in the study area.

Keywords: ReadyToEat Food Products, Preference, Satisfaction, And Working Women

\section{INTRODUCTION}

The word 'food' refers to the chemical substances taken into the body to keep the body in a healthy and active condition. The body requires nourishment for development, fix, and substitution of its exhausted tissues. Subsequently, the food needs to give the necessary crude material, energy, and other controlling for the smooth working of the body, other than meeting the calorific prerequisites like sugars, proteins, fats, and so forth Swamy et al. (2012). The food propensities in India have changed because of western impact, and the utilization of these food sources is additionally on 
the ascent. These food sources are generally utilized in catering enterprises, just as at homes. There are assortments of prepared to-eat food sources accessible in the market to browse, and they have become a piece of ordinary day-to-day existence. It is a food upheaval that has been bound to happen. Readymade food varieties are helpful in numerous individuals in different circumstances. The protected and supportive strategy for putting away, pressing, and devouring these food sources is helpful for the functioning individuals as they don't have to stress over making food. Essentially, it is simple for individuals to convey these stuffed instant food sources while they travel as it is simple for them to eat progressing Revathy et al. (2014). The food propensities in India have changed because of western impact, and the utilization of these food varieties is additionally rising. These food varieties are generally utilized in catering enterprises, just as at homes. There are assortments of prepared to-eat food sources accessible in the market to look over, and they have become a piece of regular day-to-day existence. It is a food upheaval that has been bound to happen. The prepared to-eat food sources are gainful to numerous individuals in different circumstances. Truth be told the protected and valuable strategy for putting away, pressing and burning-through these food sources is useful for the individuals who are filling in as they don't have to stress over making food. Also, it is simple for individuals to convey these pressed instant food sources while they travel as it is simple for them to eat moving. Therefore, the present study is undertaken to assess the working women preference and satisfaction of ready-to-eat food products in the study area.

\section{NEED FOR THE STUDY}

Food gives vital sustenance to the vital individual. Because of the distinctions in culture, geographic areas, climate, and environment, food things shift from one society to another. In Chennai city, the propensity for making readymade food is changing quickly. Individuals who are living in the city have a high propensity to burn through readymade food. The justification for the change is the time factor. The functioning ladies don't have a lot of time to plan food at their home. As society creates, monetary exercises likewise extend. In this manner, working ladies become occupied, and that deters them from planning food at their home. The solitary option is to devour food that is set up by others and ideally light. While working women prefer ready-to-eat food, several factors are considered by them. Hence, this study was proposed to identify the preferences and satisfaction of consuming the ready-to-eat food products in Chennai city

\section{REVIEW OF LITERATURE}

Babu et al. (2021)established that the elements, specifically Convenience, Quality, Price, and without stress, Sensory Appeal, Mood, essentially affecting the purchas- 
ing aims of Ready-to-Eat food items among the buyers. Plus, the scientist (Inbalakshmi et al. (2020) ) uncovers that the individual variables don't have any relationship with and mate work don't affect month to month use on prepared to-eat cost on moment food items, family type, occupation, brand inclinations, family month to month pay. The examination additionally tracked down a critical effect of financial components on month-to-month readymade cooking materials and the family month to month pay and mate business things. Besides, the occupation and family type don't influence month to month use on the ad. Playing a preeminent presentation in driving the clients towards moment food builds up the affirmation that pressing, cleanliness, cultural impact, and the significance of affecting the readymade food materials. Swathy (2018) referenced that today prepared to prepare food items to connect with a real spot in the kitchen racks. The twofold parts of ladies shift their cooking conduct towards the purchasing of RTC food sources. The energizing end is that accommodation is the most basic factor affecting ladies' mentality towards such items. Comfort prepared accessibility and saving of time is the explanations behind utilizing prepared to-prepare food items. It was seen in the investigation that there is a finished consciousness of RTC food items among ladies, and Nestle is the biggest part famous brand among RTC food items. Working ladies don't have adequate opportunity to set up a dinner by following the customary fixings and favors purchasing RTC food items. The purchaser's relationship with food and other ordinary merchandise has expanded drastically, in the manner in which items are bought as well as how they are burned-through. A comprehension of the RTC food utilization and ladies' disposition towards RTC food sources helps advertisers in getting they're and subsequently fabricate and distribute such item. Thienhirun and Chung (2018) they portrayed that Thai and Japanese individuals had negative perspectives toward the flavor and newness of diverse RTE food. Moreover, these two components were the principally concerned variables when they resolved to buy RTE food. The picture of Thai/Japanese RTE food could be addressed by the characters and the well-known food name. The outcomes from the conjoint investigation showed that Thai purchasers favored the changed taste among Japanese and Thai flavors. The food bundling configuration ought to be a cleared compartment cover with the mark to see the food inside. Despite what is generally expected, Japanese buyers favored a true Thai taste, and the plan ought to be the vivid plan on the food holder top. Isher et al. (2018) uncovered an emotional standpoint towards the moment Ready to eat food items, and the interest has additionally evolved. Organizations should focus more on quality advancements. The individuals had extended familiarity with the item and fitting data wellsprings of the item. The occurrence of devouring prepared to-eat food has been ascending with a general significance of comfort, efficiency, and an overall decrease in ongoing food and dietary patterns. In this tendency was more apparent in youthful customers. The examination uncovered that the prevalence of the respondents had arranged choices in buying moment food items. TV played out a critical part in giving information about moment food items. Shanmugapriya and Sri- 
varshini (2018)recognized that most of the respondents have bought moment food items consistently. Lesser time taken for arrangement is the primary justification for buying moment food items. Purchasers are happier with the accessibility of moment food items. This study will be helpful to the manufacturers of instant products for understanding the customer's choices and preferences. Patel and Rathod (2017) represents the variety of variables influencing our prepared to-eat food inclinations. Second, the scientist expects to outline variables influencing prepared to-eat food decisions and the natural dynamic cycle utilized for food inclination and decision. Third, the researcher provides a brief discussion regarding the connection between food preferences and food choices. Finally, the study concludes by stating that further insight is needed into cultural, historical, and demographic factors. Kumar and Kaur (2016) Markfed's client base predominantly comprised of youthful, exceptionally taught, and salaried class individuals. A large portion of them utilized the RTE results of Markfed just once every month. Female clients favored these RTE items day by day. With Effective commercial and special methodologies, the client base and utilization recurrence for RTE results of Markfed can be expanded for the more up-to-date markets of Punjab and all over India. Gupta and Raghbir (2016) portrays that 'comfort' is the main factor that impacts the mentalities of working ladies towards accommodation food items as this factor clarifies the $13.613 \%$ of the wide fluctuation. It is trailed by another five factors, for example, 'tactile factors,' 'state of mind,' 'medical problems,' 'value impact,' and 'knowledge of the food items. The respondents have expressed that they favor comfort food sources because of their occupied and furious way of life. Every one of these variables, by and large, represents that expanded time pressing factors, stresses, and balance of fun and serious activities issues are progressively being looked at by working ladies. Working ladies need more of an ideal opportunity to set up dinner from scratch by resulting in the conventional plans and would like to purchase pressed, clean, and reasonably evaluated suppers instead of getting back after working all day and doing homegrown tasks. Understanding the convenience food consumption patterns and the attitudes of working women helps marketers understand the needs of the consumers and accordingly manufacture and market such food products. Overall, the convenience food market in India is currently at a very emerging stage. Demand for these products is increasing day by day. Need for convenience, rise in the number of working women, health consciousness, increase in the number of organized retail sector, advancement in the food production technology and entry of international players are key factors that influence the attitudes towards convenience food products and resulted in to significant growth in this market. By understanding the attitudes of working women, food manufacturers might better estimate the successful entry in new markets. Mhab de et all. (2018)As favored women, they need to take care of both their homes and family alongside their work. As the work propensities for ladies have expanded it affects way of life, this has changed the cooking example of the functioning ladies and all the more excessively working ladies favor prepared to prepare feast. As the working hours are eight hours 
or more than that women don't have that energy and time to cook like every day, as the responsibilities lies of women for cooking. Readymade food has become a very important item in people's life as it is ready made and easy to cook and serve. As the society develops the economic activities also expand. Most of the working women prefer ready to cook meal as they be exhausted after their work this is the main reason why they prefer ready to cook meal.

\section{OBJECTIVES OF THE STUDY}

1. To study the working women's preferential behavior towards the consumption of Ready-to-Eat food products in the study area; and

2. To assess the satisfaction level among the working women on the consumption of Ready-to-Eat food products in the study region.

\section{HYPOTHESES}

1. The working women's do not prefer the usage of Ready-to-Eat food products

2. There is no significant difference between working women working government and private organizations concerning the Preference for Ready-to-Eat food products

3. The working women are not satisfied with using Ready-to-Eat food products in the study area

\section{RESEARCH METHODOLOGY}

The study is focused on assessing the Working women's Preference and satisfaction with ready-to-eat food products in Chennai city. The study used primary and secondary data-the secondary data obtained from the research articles, daily newspapers, and magazines. The primary data is collected from the working women who are using Ready-to-Eat food products. The preliminary data sourced from the working women through structured questionnaires at their working place and residence. The study employed the convenience sampling method. Overall, 300 questionnaires were distributed, out of which 291 filled questionnaires were collected from the working women. The study presumption is pinched based on these sample results. The study used SPSS version 21 software for analysis. The study used frequency distribution, one-sample t-test, and Independent t-test.

\section{DATA ANALYSIS AND DISCUSSIONS}

Table 1 shows theworking women's details. Out of 291 working women, majority $37.5 \%$ of working women are in the age group of between 26-35 years, followed by $33.7 \%$ of the working women are up to 25 years, $16.5 \%$ of working women are in 


\begin{tabular}{|c|c|c|}
\hline & Frequency & Percent \\
\hline \multicolumn{3}{|l|}{ Age (Years) } \\
\hline Up to 25 & 98 & 33.7 \\
\hline $26-35$ & 109 & 37.5 \\
\hline $36-45$ & 48 & 16.5 \\
\hline Above 45 & 36 & 12.4 \\
\hline \multicolumn{3}{|l|}{ Marital Status } \\
\hline Married & 156 & 53.6 \\
\hline Single & 135 & 46.4 \\
\hline \multicolumn{3}{|c|}{ Educational qualification } \\
\hline Up to +2 & 29 & 10.0 \\
\hline Under Graduate & 105 & 36.1 \\
\hline Post Graduate & 92 & 31.6 \\
\hline Professional & 65 & 22.3 \\
\hline \multicolumn{3}{|l|}{ Monthly Income } \\
\hline Up to Rs.30,000 & 67 & 23.0 \\
\hline Rs.30,001 -60000 & 103 & 35.4 \\
\hline Rs.60,001-90,000 & 71 & 24.4 \\
\hline Above Rs.90,000 & 50 & 17.2 \\
\hline \multicolumn{3}{|c|}{ Occupational Status } \\
\hline Private & 167 & 57.4 \\
\hline Govt. & 124 & 42.6 \\
\hline \multicolumn{3}{|l|}{ Family type } \\
\hline Nuclear Family & 223 & 76.6 \\
\hline Joint Family & 68 & 23.4 \\
\hline \multicolumn{3}{|c|}{ Members of the family } \\
\hline $2-4$ & 213 & 73.2 \\
\hline $4-6$ & 46 & 15.8 \\
\hline Above 6 & 32 & 11.0 \\
\hline
\end{tabular}

the age group of $36-45$ years, and $12.4 \%$ of the working women are in the age group of above 45 years. Regarding the marital status, most $53.6 \%$ of the working women are married, and $46.4 \%$ of the working women are single category. In connection with the educational qualification of working women, majority $36.1 \%$ of the working women educational background is under-graduates, followed by $31.6 \%$ of the working women educational background is post-graduates, $22.3 \%$ of the working women educational background is professional, and $10.0 \%$ of the working women educational background is up to HSC. The study also established that majority $57.4 \%$ of the working women are working in private organizations, and $42.6 \%$ of the working women are working in government organizations. Regarding the monthly income of working women, the majority, $35.4 \%$ of the working monthly income, is between Rs.30, $001-60000$. It is followed by $24.4 \%$ of working women's monthly income is between Rs.60, $001-90,000$, and $17.2 \%$ of the working monthly income is above 
Rs.90 000. Besides, majority 76.6\% working women's family type is nuclear family, and $23.4 \%$ of the working women's family type is a joint family. Regarding the members in the family, the majority $73.2 \%$ of the working women family size is $2-4$ members, and $11.0 \%$ of working women family members are above six members.

\section{Null Hypothesis-1}

The working women's do not prefer the usage of Ready-to-Eat food products

Table 2 llustrates the results of a one-sample t-test for Preference for the usage of Ready-to-Eat food products. The mean range of fundamental factors of Preference of using Ready-to-Eat food products is 3.18 to 3.45. The study results also exhibit that the fundamental factor's mean values are $>2.50$. It is above the average level for using Ready-to-Eat food products. The p-value of fundamental factors is $<0.05$. Therefore, the proposed null hypothesis rejected and concluded that the working women are positively preferred using Ready-eat-food products. The study's outcome exhibits that the factor 'Habit' (3.45) significantly influences the Preference of Ready -eatfood products. It is followed by 'Quality' (3.41), 'Trust' (3.34), and 'Affordable price' (3.31). Overall, working is preferred for using the Ready eat food products positively.

Table 2 One-sample t-test Results for Preference for the usage of Ready-to-Eat food products $(n=291)$

\begin{tabular}{ccccc}
\hline Preference & Mean & SD & t & p \\
Easy Accessibility & 3.26 & 1.397 & 3.148 & $0.002^{* *}$ \\
\hline Affordable prices & 3.31 & 1.399 & 3.688 & $<0.001^{* *}$ \\
Trust & 3.34 & 1.398 & 4.109 & $<0.001^{* *}$ \\
Good Quality & 3.41 & 1.207 & 3.074 & $<0.001^{* *}$ \\
Ambience & 3.30 & 1.403 & 3.635 & $<0.001^{* *}$ \\
\hline Habit & 3.45 & 1.209 & 6.351 & $<0.001^{* *}$ \\
\hline
\end{tabular}

\section{Null Hypothesis-2}

There is no significant difference between working women working in government and private organizations concerning the Preference for Ready-to-Eat food products

Table 3 describes theresults of the Independent t-test for government and private working women concerning the Preference of Ready-to-Eat food products. The study's outcome exhibits that the factors, i.e., 'Good Quality (t\& p-value), are 3.635 \& 0.000 .

The p-value is $<0.01$, the null hypothesis was rejected and concluded that there is a significant difference between private and government working women concerning the Preference of ready-to-eat food products in the study area.

The study also found that the working women working in private organizations are significantly preferred for ready-to-eat food products than the women working in government organizations. The rest of the factor's p-values are $>0.05$.

Therefore, the study confirmed no significant difference between government and private working women concerning the Preference for ready-to-eat food products. 


\begin{tabular}{|c|c|c|c|c|c|c|}
\hline & Place of working & $\mathbf{N}$ & Mean & SD & $\mathbf{t}$ & $\mathbf{p}$ \\
\hline \multirow[t]{2}{*}{ Easy Accessibility } & Private & 167 & 3.22 & 1.515 & -.512 & 0.609 \\
\hline & Govt. & 124 & 3.31 & 1.224 & & \\
\hline \multirow[t]{2}{*}{ Affordable prices } & Private & 167 & 3.40 & 1.439 & 1.315 & 0.190 \\
\hline & Govt. & 124 & 3.18 & 1.338 & & \\
\hline \multirow[t]{2}{*}{ Trust } & Private & 167 & 3.47 & 1.388 & 1.939 & 0.054 \\
\hline & Govt. & 124 & 3.15 & 1.397 & & \\
\hline \multirow[t]{2}{*}{ Good Quality } & Private & 167 & 3.44 & 1.446 & 3.635 & $<0.001^{* *}$ \\
\hline & Govt. & 124 & 2.82 & 1.432 & & \\
\hline \multirow[t]{2}{*}{ Ambience } & Private & 167 & 3.39 & 1.396 & 1.275 & 0.203 \\
\hline & Govt. & 124 & 3.18 & 1.409 & & \\
\hline \multirow[t]{2}{*}{ Habit } & Private & 167 & 3.43 & 1.148 & -.311 & 0.756 \\
\hline & Govt. & 124 & 3.48 & 1.291 & & \\
\hline
\end{tabular}

\section{Null Hypothesis-3}

The working women are not satisfied with using Ready-to-Eat food products in the study area

Table 4 shows the results ofthe One-sample t-test for the satisfaction of using the Ready-to-Eat food products in the study area. The calculated t \& p-value for satisfaction of using ready-to-eat food products is $6.156 \&<0.001$. The p-value is $<0.01$; based on the p-value, the study inferred that the working women are absolutely satisfied with using the ready-to-eat food products in the study region.

Table 4 One-sample t-test for the satisfaction of using the Ready-to-Eat food products

\begin{tabular}{lccccc}
\hline Satisfaction of using Ready-to-Eat & N & Mean & SD & t & p \\
& 291 & 3.43 & 1.200 & 6.156 & $<0.001^{* *}$
\end{tabular}

\section{CONCLUSION}

The study is focused on measuring the working women's Preference and Satisfaction with Ready-To-Eat Food Products in Chennai City. It is observed from the study the working women are positively preferred using Ready-eat-food products. The working women's felt that the ready-to-eat food products readily available for the preparation of food products. The working women also viewed that the availability of readyto-eat food products quickly. The working women also felt that the ready-to-eat food products are quality and affordable prices. The study also originates a significant difference between private and government working women concerning the Preference for ready-to-eat food products in the study area. The study also found that the working women working in private organizations are significantly preferred for ready-to- 
eat food products than the women working in government organizations. The study also established that the working women are delighted with using the ready-to-eat food products in the study region.

\section{REFERENCES}

Babu, R. S., Balaji, V., \& Gajenderan, V. (2021). FACTORS INFLUENCING TOWARDS THE PRUCHASE INTENTIONS OF READY-TO-EAT FOOD PRODUCTS AMONG THE CONSUMERS IN CHENNAI CITY. International Journal of Research -GRANTHAALAYAH, 8(12), 172-181. Retrieved from https://dx.doi.org/10.29121/granthaalayah.v8.i12 .2020 .2702 10.29121/granthaalayah.v8.i12.2020.2702

Gupta, R., \& Raghbir. (2016). Working Women's Attitudes Towards Convenience Food Products: An Empirical Investigation. Pacific Business Review International, 1(3).

Inbalakshmi, M., Govindarajan, K., Vijaya, C., Vijayanand, V., \& Inbalakshmi, M. (2020). A Study On Consumer Preference Towards Organic Food Products In Tamilnadu. Journal OfXidian University(5), 14-14.

Isher, A. K., Kachroo, J., Dwivedi, S., Bhat, A., \& Singh, S. P. (2018). Consumer Behaviour And Consumption Pattern Towards Ready To Eat Food Products In Jammu City. Consumer Behaviour And Consumption Pattern Towards Ready To Eat Food. Products In Jammu City, 4, 5-9.

Kumar, M., \& Kaur, P. (2016). Consumer Preferences And Awareness Towards Ready To Eat Products Of Cooperatives -A Case Of Markfed. / International Journal of Management Research \& Review, 6(18), 2249-719659.

Mhabde, R., Thakkar, P., \& Dhamani, A. (2018). An Analytical Study On The Working Women's S Preference Towards Convenience Quick Foods. Ijariie, 4(2), 1146-1152.

Patel, D., \& Rathod, R. (2017). Ready To Eat Food Perception, Food Preferences, And Food Choice: A Theoretical Discussion. World Wide Journal Of Multidisciplinary Research And Development, 3(8), 198-205.

Revathy, D. B., , \& Salomi, M. R. S. (2014). A Study on the Preference of Working Women towards Readymade Food in Tirunelveli District. IOSR Journal of Humanities and Social Science, 19(6), 61-70. Retrieved from https://dx.doi.org/10.9790/0837-1961617010 .9790/0837-19616170

Shanmugapriya, S., \& Srivarshini, V. (2018). Consumers Preference And Satisfaction On Instant Food Products. Think India Journal, 3(1), 220-224.

Swamy, B., Kumar, T. A., \& Srinivasa, R. K. (2012). Buying Behaviour Of Consumers Towards Instant Food Products (A Study Done At Hyderabad City Of Andhra Pradesh State, India). International Journal of Research And Computational Technology, 2(2), 9755465.

Swathy, P. (2018). A Study On Buying Behavior Towards Ready To Cook Food Among Working Women With Special Reference To Ranni Taluk. International Journal of Advanced Research In Science Management And Technology, 4(2), 1-10.

Thienhirun, S., \& Chung, S. (2018). Consumer Attitudes and Preferences toward CrossCultural Ready-To-Eat (RTE) Food. Journal of Food Products Marketing, 24(1), 5679. Retrieved from https://dx.doi.org/10.1080/10454446.2016.1266544 10.1080/ 10454446.2016 .1266544 